\title{
ASSESSING THE IMPACT OF CLIMATE CHANGE ON WATER SUPPLY AND FLOOD HAZARD IN IRELAND USING STATISTICAL DOWNSCALING AND HYDROLOGICAL MODELLING TECHNIQUES
}

\author{
ROSEMARY CHARLTON, ROWAN FEALY, SONJA MOORE, JOHN SWEENEY \\ and CONOR MURPHY \\ Department of Geography, National University of Ireland, Maynooth, County Kildare, Ireland; \\ E-mail:Ro.Charlton@nuim.ie
}

\begin{abstract}
Estimates are made of changes in effective runoff at a high spatial resolution for the island of Ireland under different climate change scenarios. The first part of the investigation examines changes in annual and seasonal effective runoff for the whole land area of Ireland. The rainfall-runoff model HYSIM is used to carry out the hydrological simulations. The output from the HadCM3 Global Climate Model (GCM) is downscaled using statistical techniques to provide precipitation and evaporation data at a $10 \mathrm{~km} \times 10 \mathrm{~km}$ resolution; this data is then used to drive the HYSIM model. Simulations are carried out for each of the $82510 \mathrm{~km} \times 10 \mathrm{~km}$ grid cells covering Ireland for the baseline period (1961-1990) and two future scenarios; 2041-2070 and 2061-2090. Parameter values are derived for each square using data from the Soil Survey of Ireland and the CORINE land use database and validation is carried out for selected catchments. The results of these simulations indicate a decrease in annual runoff that is most marked in the east and southeast of the country, whereas an increase is likely for the extreme northwest. The reduction in effective runoff for the east of the country is particularly marked during the summer months. It is these areas that have highest population density and also where greatest population growth is likely to occur. During the winter months an increase in effective runoff is suggested for the western half of country which could have implications for flood frequency, as well as the extent and duration of winter flooding.
\end{abstract}

\section{Introduction}

Although Ireland is relatively well endowed with water resources, regional shortages can occur at certain times of the year, especially in the east and southeast of the country. The rapid expansion of urban areas such as Dublin, Cork, and Limerick, associated with recent economic conditions, is putting an increasing strain on the water supply infrastructure. The increased demand for water comes mainly from the industrial and domestic sectors, with domestic demand increasing both as a result of population growth and rising water consumption per capita. As a result, low flows are becoming more frequent in some areas and it is likely that future climate change scenarios will exacerbate these effects. At the same time, many Irish rivers are prone to flooding, especially those in the west, with the Shannon being a prime example. Increases in winter precipitation over the western part of the island are likely to increase the magnitude and frequency of flood events, and increase the duration of seasonal flooding. The aim of this research, therefore, is to simulate patterns of runoff under baseline and future 
climate scenarios, at a fine spatial resolution, in order to assess annual and seasonal changes.

Most of the present water supply in Ireland comes from surface water, with $20-25 \%$ coming from groundwater. In some counties the groundwater proportion is much greater, and in many rural areas that have no access to a public or group supply scheme, groundwater from wells provides the only source of water (Daly and Warren, 1998). Water availability fluctuates over time and through space and is dependent on the balance between precipitation and evapotranspiration. The runoff yield from an area, usually that of a catchment (drainage basin), over a period of time can be calculated using the water balance equation:

$$
\mathrm{RO}=P-\mathrm{AET} \pm \Delta S
$$

where, RO is the runoff, $P$ the precipitation, AET the actual evapotranspiration, and $\Delta S$ the changes in storage.

The storage term includes water stored as groundwater; in lakes and reservoirs; and as soil moisture. The volume of water held in storage fluctuates through time in response to changes in the balance between rainfall inputs and evaporative and transpiration losses. Characteristics such as soil permeability, geology and topography all determine the response to precipitation, in addition to flow recession characteristics and the duration of baseflow between rainfall inputs. The baseflow contribution is particularly important in the context of climate change scenarios that indicate dryer summers because the frequency and duration of low flows are likely to increase as a result.

\section{Climate Change and Water Resources in Ireland}

\subsection{OBSERVED LINKAGES BETWEEN CLIMATE CHANGE AND HYDROLOGY}

A number of studies have been carried out to examine the linkages between climate variables, especially circulation types and precipitation, and subsequent runoff. A significant correlation was found by Shorthouse and Arnell (1999), who concluded that precipitation and the resultant runoff are strongly correlated with the North Atlantic Oscillation index (NAO). Increased rainfall caused by strengthened westerlies (positive NAO) has been observed for northern and western Europe, while at the same time southern and central Europe have experienced drying. An increase in winter storminess has also been observed by a number of authors for Britain (Conway, 1998; Lovelace, 2000; Hulme and Barrow, 1997) and Ireland (Houghton and Cinneide, 1976; Sweeney, 1985; Sweeney and O'Hare, 1992). Irish studies have found changes in the synoptic patterns of Irish precipitation, identifying a reappearance of westerly circulation frequencies along the northern and western parts of Britain and Ireland during the 1980s and 1990s (Sweeney, 1997). These westerly winds, together with a decrease in anticyclonic easterlies, are thought to 
be responsible for the rise of autumn and winter storm events in Dublin in the latter half of the 20th century (Sweeney, 2000). Increases in annual precipitation and streamflow have been observed by Kiely (1999) who tested observations from selected sites for climatic and hydrological change. Streamflow was found to show similar trends to precipitation data, with the increase occurring after 1975 and being most noticeable in the west of the island.

\subsection{RUNOFF UNDER FUTURE CLIMATE CHANGE SCENARIOS}

Although a number of studies have investigated the impact of future climate scenarios on water resources for Britain (Arnell 1992, 1996; Arnell and Reynard, 1993, 1996; Boorman and Sefton, 1997; Pilling and Jones, 1999), little work has so far been carried out for Ireland. Cunnane and Regan (1994) used a hydrological model applied to the Brosna catchment (a tributary of the Shannon) to simulate runoff under four prescribed climate scenarios for the year 2030. Under these scenarios precipitation and evaporation were increased on an annual basis, or seasonally on the basis of increased winter and decreased summer precipitation. The results indicated that although the magnitude of high and low flows would be only slightly greater than those observed within the range currently experienced, the frequency of flood and drought events would be likely to increase within that catchment.

Recent research in Britain has examined the spatial pattern of changing runoff for the whole land area of Britain (Arnell, 1992, 1996; Arnell and Reynard, 1993; Pilling and Jones, 1999). Although the grid squares used do not represent actual drainage basins, such studies allow changing spatial patterns of annual and seasonal runoff to be considered and provide a valuable starting point for further research focusing on selected drainage basins. Advances in downscaling techniques have allowed hydrological modelling to be carried out at increasingly high spatial resolutions, with the $10 \mathrm{~km} \times 10 \mathrm{~km}$ resolution used by Pilling and Jones (1999) constituting the highest resolution to date. Pilling and Jones used downscaled Global Climate Model (GCM) output for 2050 (UKHI) and for 2065 (transient UKTR) to drive a hydrological model and simulate annual and seasonal effective runoff for Britain. Effective runoff is the total depth of runoff yielded by an area over a given time period e.g. annually or seasonally and is normally expressed as a depth of water in $\mathrm{mm}$ covering the area under consideration. Whereas this had previously been carried out using relatively simple water balance models (Arnell, 1992, 1996; Arnell and Reynard, 1993), Pilling and Jones used a physical process-based hydrological model to simulate runoff. This allowed a more detailed representation of the land surface through the use of physically realistic parameters and processes.

Since there has not been any previous attempt to model runoff for the whole land area of Ireland under future climatic scenarios, the present study is an initial investigation. A grid-based approach, based on that of Pilling and Jones, was adopted. It has been necessary to make some simplifying assumptions, and certain aspects, such as the representation of storage as groundwater, soil water, lakes etc., are somewhat 
crude. However, in addition to giving some indication of spatial changes in runoff for Ireland, the study also provides a useful learning experience in the application of various techniques and in assessing the validity of the approaches used.

\section{Derivation of the Climate Data}

\subsection{BASELINE CLIMATE}

In order to derive the baseline climatology, monthly climate data were obtained for the Republic of Ireland from Met Éireann and, for Northern Ireland, from the British Atmospheric Data Center. This amounted to 570 stations recording precipitation and 65 for temperature. Data for global solar radiation, sunshine hours and potential evaporation were also acquired for as many stations as possible. A criterion of $70 \%$ data capture was applied to each station and those that failed to meet this were rejected. In order to derive a climate 'surface' for each variable, the observed monthly climate variables from the recording stations were related to the position and elevation of each station on the Irish National Grid (northings and eastings). A polynomial regression technique was then used to derive a gridded baseline climatology at a scale of $1 \mathrm{~km}^{2}$ (Goodale et al., 1998). The use of the polynomial equation appears to adequately capture many of the key spatial trends in the Irish climate with a coast-interior-coast contrast superimposed on a southwest-northeast latitudinal gradient. For example, winter temperatures in Ireland do show a coastinterior-coast contrast as the dominant spatial feature, while summer temperatures have a more overt latitudinal control apparent. Table I displays results, $R^{2}$ and standard errors from the polynomial regression and indicates the suitability of this method for deriving climatic 'surfaces' from Irish climate data.

\subsection{STATISTICAL DOWNSCALING}

Over recent years there have been considerable developments in the capabilities of GCMs, brought about by advances in understanding of the atmospheric system and an increase in available computing power. However, the grid size, typically of the order of $2.5^{\circ} \times 3.75^{\circ}$, is generally at too coarse a scale to be suitable for use in most impact studies. As a result, various methods for downscaling GCM output to a finer spatial resolution have been developed. These vary in complexity from the relatively simple approach of pattern scaling, to much more sophisticated techniques, using one of two approaches: statistical downscaling or Regional Climate Models (RCMs). Pattern scaling, which assumes climate changes are the same from place to place irrespective of altitude or location within the grid, was considered unsuitable for this study because it would not allow spatial variations in runoff change under future scenarios to be considered. A statistical downscaling technique was selected in favour of the available RCM data for Ireland from the UK Climate Impacts 
TABLE I

Polynomial regression statistics for maximum temperature, minimum temperature and precipitation for the baseline climatology

\begin{tabular}{|c|c|c|c|c|c|c|}
\hline \multirow[b]{2}{*}{ Month } & \multicolumn{2}{|c|}{ Maximum temperature } & \multicolumn{2}{|c|}{ Minimum temperature } & \multicolumn{2}{|c|}{ Precipitation } \\
\hline & $R^{2}$ & SE & $R^{2}$ & SE & $R^{2}$ & SE \\
\hline January & 0.91 & 0.25 & 0.63 & 0.58 & 0.74 & 26.63 \\
\hline February & 0.95 & 0.19 & 0.69 & 0.53 & 0.75 & 18.60 \\
\hline March & 0.90 & 0.25 & 0.69 & 0.50 & 0.71 & 20.07 \\
\hline April & 0.80 & 0.34 & 0.63 & 0.53 & 0.71 & 11.67 \\
\hline May & 0.70 & 0.41 & 0.62 & 0.54 & 0.69 & 12.81 \\
\hline June & 0.78 & 0.40 & 0.66 & 0.46 & 0.71 & 10.97 \\
\hline July & 0.85 & 0.38 & 0.67 & 0.43 & 0.73 & 12.04 \\
\hline August & 0.83 & 0.34 & 0.57 & 0.54 & 0.69 & 15.66 \\
\hline September & 0.86 & 0.28 & 0.62 & 0.54 & 0.74 & 17.69 \\
\hline October & 0.92 & 0.18 & 0.57 & 0.52 & 0.77 & 21.70 \\
\hline November & 0.91 & 0.23 & 0.66 & 0.58 & 0.76 & 21.48 \\
\hline December & 0.91 & 0.24 & 0.61 & 0.58 & 0.75 & 25.10 \\
\hline
\end{tabular}

Programme RCM, UKCIP01, as the spatial resolution of $50 \mathrm{~km}$ was considered too coarse for this application.

Statistical downscaling involves using an empirical statistical technique to establish linkages between surface observations and mesoscale predictor variables such as geopotential heights, vorticity and humidity, for a baseline period. These relationships are then used to downscale future climate scenarios using GCM output. The technique assumes that GCMs simulate mesoscale aspects of climate better than surface variables such as temperature and precipitation (Palutikof et al., 1997) and that the relationship will remain robust in a changing climate. In order to account for some bias which may occur within a GCM, the difference between modelled future and modelled present climate scenarios are then applied to the observed baseline.

The UK Meteorological Office coupled ocean-atmosphere model HadCM3 was selected to provide the GCM data. This has a grid resolution of $2.5^{\circ} \times$ $3.75^{\circ}$, providing a surface resolution of $240 \mathrm{~km} \times 278 \mathrm{~km}$ in the vicinity of Ireland. The simulation used (HadCM3GGa1) is based on historical increases in individual greenhouse gases from 1860-1990 and then partly on emission scenario IS95a. This produces global temperature increases of approximately $3.5^{\circ}$ by 2100.

Mesoscale data for the Irish domain, from the National Center for Environmental Prediction/National Center for Atmospheric Research (NCEP/NCAR) Reanalysis Project, was re-gridded from $2.5^{\circ} \times 2.5^{\circ}$ to conform with the output from the GCM. A parsimonious selection of predictors for the mesoscale data was 
TABLE II

Validation summary using independent dataset for the period 1991-1997

\begin{tabular}{lcll}
\hline Climate variable & $\begin{array}{l}\text { Range Pearson's } \\
' r ' \text { (monthly) }\end{array}$ & $\begin{array}{l}\text { Mean average } \\
\text { error (MAE) }\end{array}$ & $\begin{array}{l}\text { Root mean square } \\
\text { error (RMSE) }\end{array}$ \\
\hline Maximum temperature & $0.23-0.94$ & $0.04{ }^{\circ} \mathrm{C}$ & $0.87^{\circ} \mathrm{C}$ \\
Minimum temperature & $0.54-0.92$ & $0.03{ }^{\circ} \mathrm{C}$ & $0.83^{\circ} \mathrm{C}$ \\
Precipitation & $0.36-0.85$ & $0.29-30.02 \mathrm{~mm}$ & $24.24-48.72 \mathrm{~mm}$ \\
Radiation & $-0.13-0.63$ & $0.35 \mathrm{MJ} / \mathrm{day}$ & $1.12 \mathrm{MJ} / \mathrm{day}$ \\
\hline
\end{tabular}

then related to a large selection of the original stations (250 stations in the case of precipitation and 60 stations for temperature) to establish relationships between the surface observations (temperature, precipitation and radiation) and the upper air variables. The mesoscale data included the height of the $500 \mathrm{hPa}$ surface, the 500-850 hPa thickness, specific and relative humidity and mean sea level pressure.

Validation of these relationships was performed using an independent dataset from 1991-1997 (Table II). In general, temperature verification was good, particularly for summer maxima. Minimum temperature was predicted well for all seasons by the technique. As expected, downscaling precipitation was less accurate at all times of the year, largely due to the heterogeneity inherent in precipitation data.

Once validated, these relationships were then used in the statistical downscaling of the GCM. Monthly outputs for the selected mesoscale variables from the HadCM3 simulation for the period 1961-2099 for the spatial domain around Ireland were extracted from the GCM. These data were then used to establish a control run and two future scenarios using the empirical relationships derived between the NCEP upper air and observed surface variables. The results from the GCM control run for the period 1961-1990 were then compared to the observed climate to ensure faithful reproduction by the GCM. Climate differences between the control and modelled runs were then applied to the observed station data to provide future climate scenarios for Ireland for two future periods: 2041-2070 and 2061-2090. In order to assess the spatial component of change - an advantage of using statistical downscaling over pattern scaling - polynomial regressions were again used to derive the climate surfaces, but for the scenario data, at a $10 \mathrm{~km}^{2}$ resolution.

There is an inherent weakness in using just one scenario run from a GCM to generate future scenarios of climate, mainly due to an inability to address uncertainties in both the forcing of the GCM parameters and future emissions. Though a more desirable approach to addressing issues of uncertainty could have been incorporated through the utilisation of ensemble runs from multiple GCMs, this was not considered feasible in an initial assessment of this nature. 


\section{Hydrological Model Simulations}

\subsection{MODEL PARAMETERISATION}

The hydrological simulation model, HYSIM (Manley, 1978, 1993), was selected for this study. It is a versatile model that has previously been used in a number of different applications, including climate change research such as that carried out by Pilling and Jones $(1999,2002)$. It is also the standard rainfall-runoff model used by the UK Environment Agency. HYSIM uses rainfall and potential evaporation data to simulate river flow, and parameters for hydrology and hydraulics that define the river basin and channels in a realistic way. The model consists of several conceptual stores between which water is transferred by means of numerical algorithms.

The $10 \mathrm{~km} \times 10 \mathrm{~km}$ grid covering the land area of Ireland that was used in downscaling was also used as the 'hydrological grid'. Soil data were obtained from the digital 1:575 000 map of the soil associations for Ireland, produced by the Soil Survey of Ireland, together with the accompanying bulletin (Gardiner and Radford, 1980a,b). The soil hydrologic parameters include porosity, permeability of the different soil layers and pore size distribution index; values for these parameters were assigned on the basis of the soil textural characteristic (Manley, 1993). The digital map was converted to the $10 \mathrm{~km} \times 10 \mathrm{~km}$ grid and the 44 soil associations reclassified into 11 soil textural groups (soil texture is defined by the relative proportions of sand, silt and clay particles). Where more than one textural class was dominant, texture was defined manually by considering the textural classification of the adjoining grid cells and their corresponding land use classification. Two additional hydrological classes were included to represent the extensive areas of blanket and raised peat, with parameter values assigned separately on the basis of field and laboratory observations of raised and blanket peat made by Galvin (1976) and Feehan and O'Donovan (1996). Parameters relating to vegetation and land use characteristics include the rooting depth of vegetation, impermeable areas, permeability of the soil surface and the rainfall intercepted by different types of vegetation. Standard values for these parameters were used (Manley, 1993) and were assigned according to vegetation type or land use class. These categories were determined using the digitised European land use database, CORINE (Coordination of Information on the Environment) (O'Sullivan, 1994). In parameterising HYSIM, land use was assigned on the basis of majority into one of seven classes: urban areas; arable land; pasture; forests, including shrubs and herbaceous plants; peat bogs; inland water bodies; little or no vegetation. One land use classification value, based on predominant land use, was assigned to each of the $10 \mathrm{~km} \times 10 \mathrm{~km}$ cells, although it was again necessary to reclassify some cells by hand. The assumption was made that land use and land cover parameters would remain unchanged in the future. Much of the groundwater in Ireland occurs in fissured shallow aquifers, many of which show some degree of solutional enlargement or karstification characteristic of certain limestones. (Daly and Warren, 1998). The grid-based approach used 
in this study presented problems for the representation of groundwater. HYSIM uses a recession coefficient determined from hydrograph analysis to integrate these aquifer characteristics. Each cell was assigned a groundwater reservoir and using an 'average' value for the recession coefficient (Manley, 1993). Although a number of the $10 \mathrm{~km} \times 10 \mathrm{~km}$ grid cells would not in reality be partly or wholly underlain by significant aquifers it was felt that assigning groundwater to all cells made fewer assumptions than allocating 'groundwater' and 'no groundwater' to different grid cells. In this study changes in effective runoff, expressed as a depth of runoff per unit area, rather than stream flow were examined and the hydraulic routines were not employed. As a result of the simplifications made the groundwater storage term effectively represented groundwater, lake and reservoir storage.

Daily precipitation and monthly potential evaporation data were required as inputs to the HYSIM model, which was run at a daily time step, and monthly precipitation values for the baseline (observed) and future climate scenarios (downscaled) were converted to daily values by distributing the monthly precipitation into mean daily values. Input files were then created in HYSIM format, each file containing two identical years of daily precipitation or monthly PE data to allow 1 year as a run-in period for the model before the actual simulation. Longer run-in periods were tested but did not produce a significant improvement in model performance.

\subsection{MODEL VALIDATION}

Although the grid cells did not represent actual catchments, it was possible to validate the output from the HYSIM model by comparing observed runoff for selected catchment areas with simulated runoff for the cells/parts of cells corresponding to these areas. As far as possible catchments were selected to represent the range of hydrological conditions found in Ireland. Gauging stations upstream from dams and reservoirs were selected on the basis of the quality and availability of data for the 1961-1990 baseline period and naturalised flows were used. The catchments selected are shown in Figure 1 and Table III. Mean monthly observed flows in $\mathrm{m}^{3} \mathrm{~s}^{-1}$ for the 1961-1990 period were converted to annual, winter (December, January, February) and Summer (June, July, August) effective runoffs in $\mathrm{mm}$ and were compared to model predictions for the catchment areas over these periods.

Table III shows the annual observed and predicted effective runoff for each of the selected catchments for the baseline period. From this it can be seen that the Feale, Slaney and Brosna all fall within $\pm 10 \%$ of the observed values, with the percentage error for the Suir slightly over $10 \%$. However, annual runoff was under-estimated by $18 \%$ for the Shannon and $23 \%$ for the Bonet; these catchments are discussed in more detail below. The seasonal errors for the Brosna, Feale, Slaney (winter) and Suir (winter) were all less than $10 \%$; these last two catchments had errors of $+20 \%$ and $-14 \%$ respectively for the summer months. The greatest errors in annual and 
TABLE III

Predicted and observed values of annual effective runoff for the catchments used in the validation of the hydrological model HYSIM

\begin{tabular}{lcccccc}
\hline & $\begin{array}{l}\text { Feale at } \\
\text { Listowel }\end{array}$ & $\begin{array}{l}\text { Suir at } \\
\text { Clonmel }\end{array}$ & $\begin{array}{l}\text { Slaney at } \\
\text { Scarawalsh }\end{array}$ & $\begin{array}{l}\text { Shannon } \\
\text { at Athlone }\end{array}$ & $\begin{array}{l}\text { Brosna at } \\
\text { Ferbane }\end{array}$ & $\begin{array}{l}\text { Bonet at } \\
\text { Dromahair }\end{array}$ \\
\hline Basin area $\left(\mathrm{km}^{2}\right)$ & 646 & 2173 & 1036 & 4597 & 1207 & 294 \\
Predicted runoff $(\mathrm{mm})$ & 1058.93 & 617.27 & 566.55 & 645.86 & 475.88 & 950.12 \\
Observed runoff $(\mathrm{mm})$ & 1070.69 & 697.00 & 565.63 & 787.97 & 441.82 & 1232.20 \\
\% Error & -1.1 & -11.4 & 0.2 & -18.0 & 7.7 & -22.9 \\
\hline
\end{tabular}

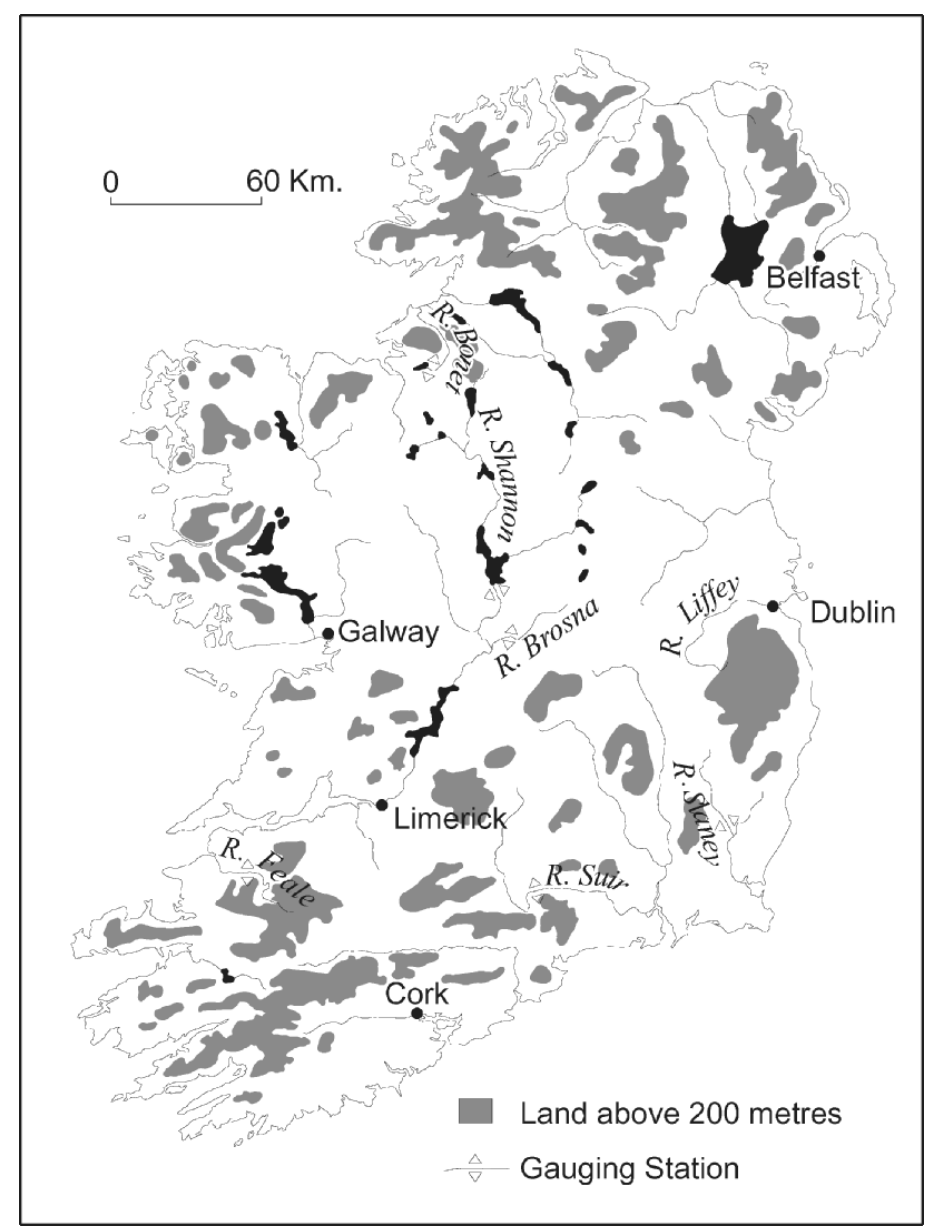

Figure 1. Rivers and upland areas in Ireland showing the locations of gauging stations used in validation. 
seasonal runoff were for the Shannon and Bonet. The Shannon catchment, upstream from Athlone, was the largest considered in this study and has extensive areas of lakes, wetlands and peat; the channel gradient is very low and there are complex interactions with groundwater. The smaller catchment of the Bonet also includes areas of peat and wetlands. Examination of the simulated winter and summer runoff for these two catchments revealed that the Shannon was under predicted in winter $(-29 \%)$ but close to the observed value in summer $(-0.6 \%)$, while the runoff from the Bonet was under predicted for both summer $(-28 \%)$ and winter $(-20 \%)$. It is possible that some of the shortfall in simulated runoff could have been brought about by the simplified representation of storage and, with this in mind, overall changes in each of the storage reservoirs were examined for selected grid squares. However, although the storage parameters did affect the relative magnitudes of monthly and seasonal runoff totals, the small changes observed at the end of the simulated year were insufficient to account for the annual shortfall in simulated runoff for these catchments. Another possibility is that the monthly precipitation input might have been under-estimated for some upland areas. This could have come about when the digital terrain model was upscaled from the $1 \mathrm{~km} \times 1 \mathrm{~km}$ to $10 \mathrm{~km} \times 10 \mathrm{~km}$ resolution, resulting in an under-representation of any individual peaks and ridges occurring within each $10 \mathrm{~km} \times 10 \mathrm{~km}$ grid square and a consequent reduction in precipitation input. While the upper Shannon, Bonet, Feale and Suir all drain upland areas, the interpolation problem would be greatest where isolated peaks occur, as is the case for parts of the upper Shannon and Bonet, and less marked for the more continuous areas of upland drained by the Feale.

In general the results of the HYSIM validation provide some support for the techniques employed and there does not appear to be a consistent bias in runoff prediction. It is important to note however that errors greater than those reported for the six validation catchments could exist elsewhere. In common with other studies of this type, several sources of uncertainty are introduced during the modeling process described. These include the choice of downscaling technique, structure of the hydrological model and model parameterization, while external uncertainties relate to the choice of emissions scenario, climate model selection and model structure. The results discussed in the following section can therefore only provide a general idea of possible outcomes, particularly where the magnitude of errors in runoff prediction is greater than the percentage change observed under the selected climate scenarios.

\section{Possible Future Changes in Effective Runoff}

Changes in annual and seasonal runoff under the two climate scenarios were examined for the validation catchments; for annual runoff these were found to be greater than the validation errors for all catchments except the Shannon and Bonet. With the exception of the Bonet, changes in summer runoff were found to be greater than 


\section{Effective Runoff 1961-1990}
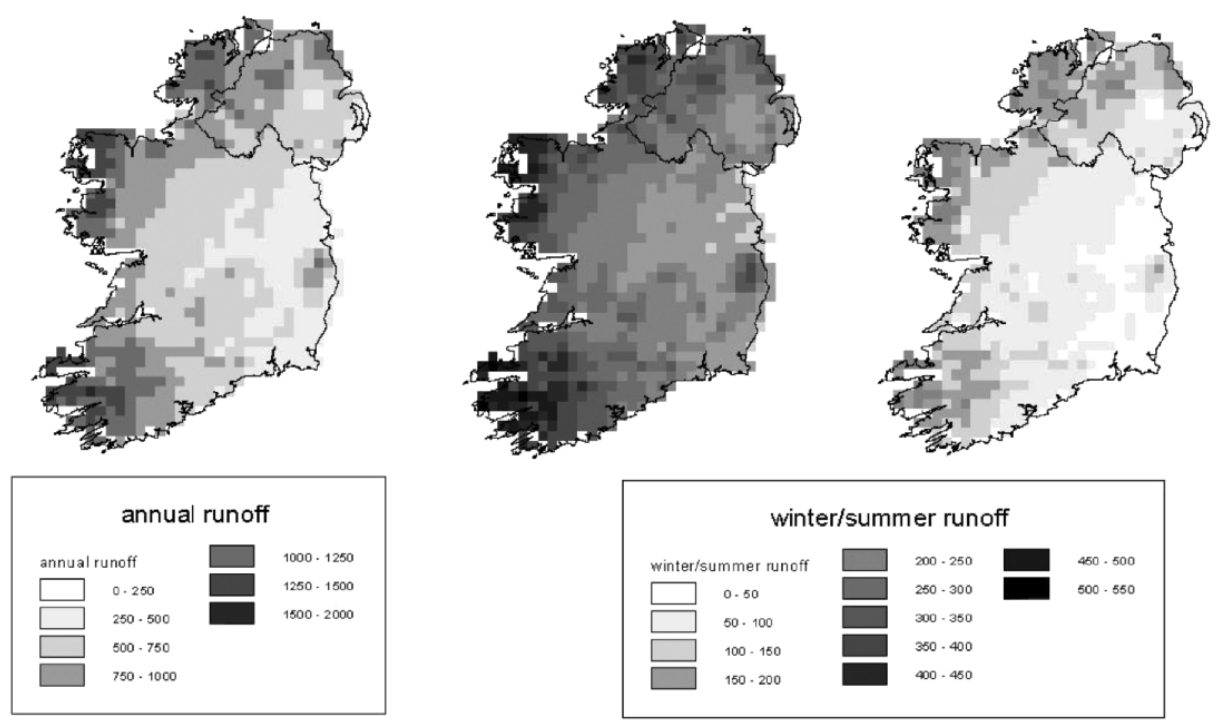

Figure 2. Simulated effective runoff in mm for the 1961-1990 baseline period showing (i) annual (ii) winter and (iii) summer effective runoff.

the errors for five of the six catchments. Greater uncertainty was associated with winter runoff, where the observed changes were greater than the validation errors for the Slaney and Feale only.

Figure 2 shows the annual effective runoff for the baseline simulation, where observed data were used to drive the model. Seasonal effective runoff for winter (December, January, and February) and summer (June, July and August) are also shown. The spatial distribution of runoff for this period reflects precipitation patterns, with an east-west gradient across which a decrease in runoff is observed. Higher runoff from upland areas is associated with localised increases in precipitation due to orographic effects. Figures 3 and 4 show the estimated percentage decrease in runoff, relative to simulated baseline runoff, for 2041-2070 and 20612090 respectively. From these maps it can be seen that the overall reduction in runoff is greater under the 2041-2070 scenario than for 2061-2090. At a regional scale these runoff patterns broadly reflect those observed in downscaled precipitation for the two scenarios, though spatial variations are seen at the grid scale, reflecting differences in soils, land use and hydrological parameters between grid squares. It is during the summer months that the greatest spatial variation occurs since effective runoff for this period is more strongly influenced by variations in storage characteristics than are winter and annual flows. General observations of changes in storage were made for selected cells by examining the variations in 


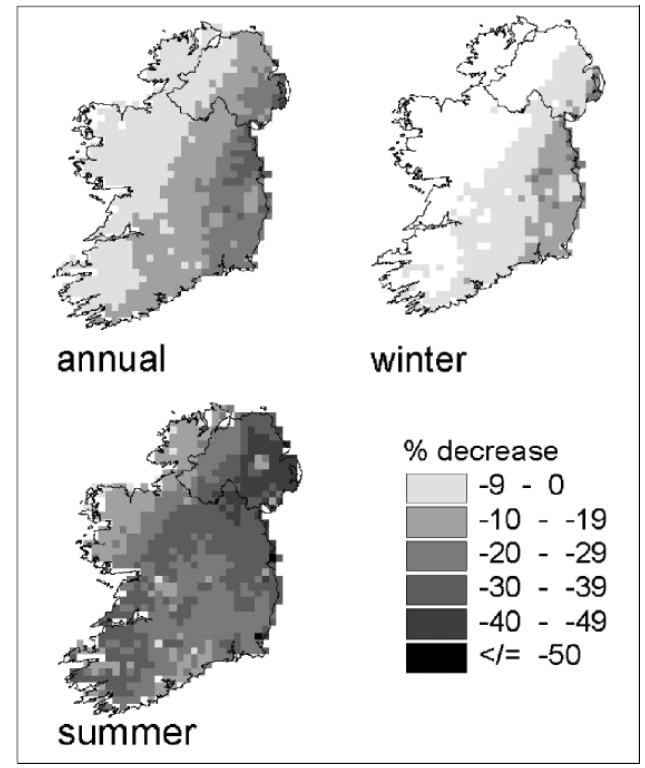

Figure 3. Percentage decreases in annual and seasonal effective runoff for the 2041-2070 scenario.

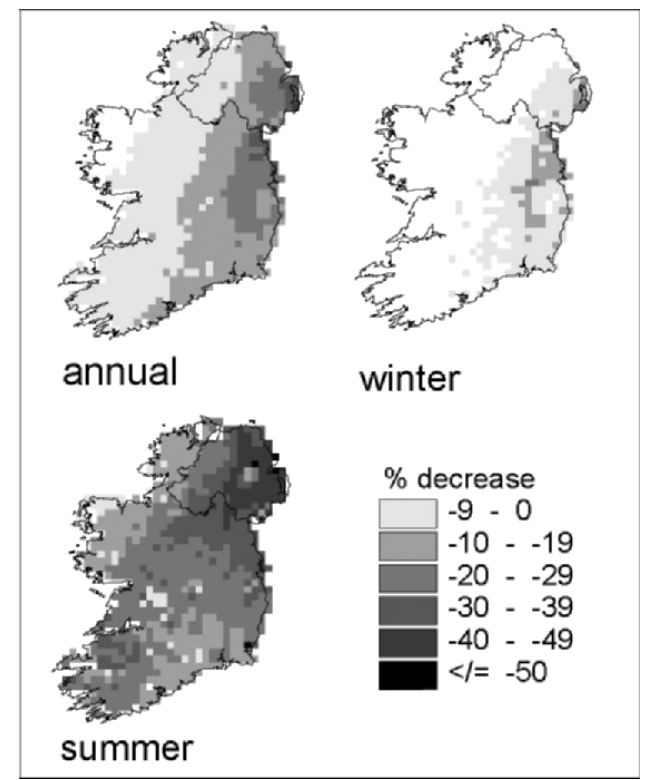

Figure 4. Percentage decreases in annual and seasonal effective runoff for the 2061-2090 scenario.

moisture storage and transfers between different stores that occurred during each simulation period. Under the 2041-2070 scenario, a slight depletion in soil moisture and groundwater storage was observed during the summer months in the west and northwest. This was accentuated in the midlands and severe in the east and 


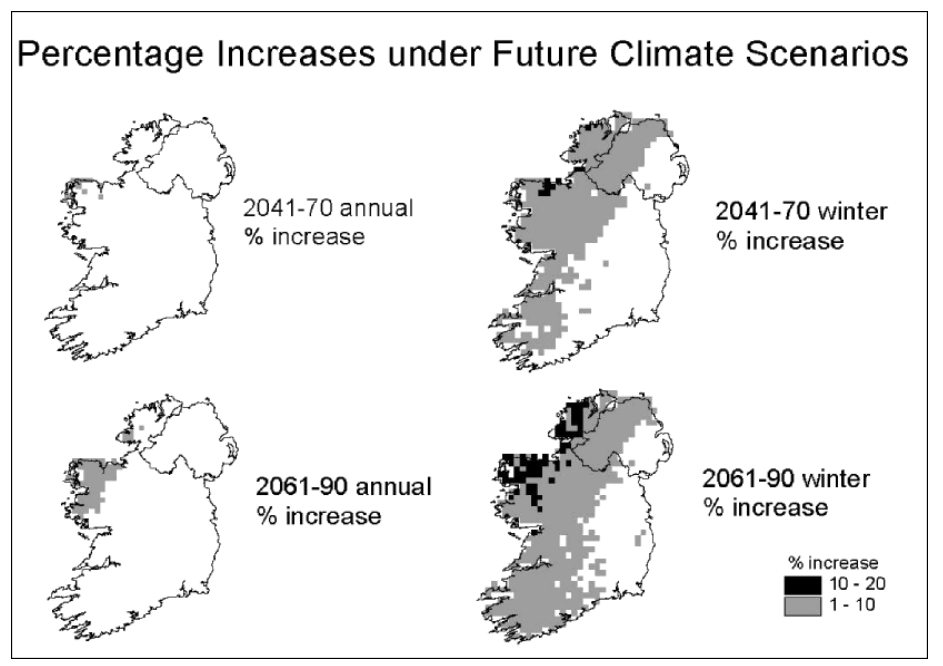

Figure 5. Percentage increases in annual and winter effective runoff for 2041-2070 and 2061-2090 scenarios.

southeast, where a temporal delay in recharge of up to 6 weeks could occur. The results suggest that under both scenarios there may be an overall decrease in annual runoff for most of the land area that is most marked in the east, an effect that is apparent both in terms of percentage and absolute changes. From Figure 5 it can be seen that an increase in annual runoff may occur over a limited part of the northwest. A greater area may be affected under the 2061-2090 scenario.

As previously mentioned, winter runoff is associated with the greatest uncertainty. In addition to this, the temporal resolution of both the input data and the model output is too coarse to provide information on flood frequency and magnitude and it is thus possible only to make general observations relating to changes in flood risk. Increases in winter runoff appear to be likely over large areas under both scenarios (Figure 5) and the land area can be roughly divided into two zones along a northeast-southwest axis, suggesting an increase in winter runoff of up to approximately $12 \%$ for the western part of the island. Under the 2061-2090 scenario, an increase in runoff is indicated over most of the land area, including the upland area of the Wicklow Mountains to the south of Dublin. The increase in winter runoff indicated for many parts of the west, especially under the 20612090 scenario, could lead to increases in the magnitude and frequency of flooding. Seasonal flooding affects many parts of Ireland during the winter months when soils are at or near saturation. The central lowlands have large areas of lakes and wetlands and seasonal flooding is a common occurrence for the rivers draining this area, which have shallow gradients along much of their length and a poor carrying capacity. An increase in runoff would probably increase the extent and duration of such flooding. 
A degree of caution should obviously be applied to the observations made above, which can only give a general idea of changes in annual and seasonal patterns of storage under the future climate scenarios considered.

\section{Management Implications}

For the climate scenarios examined, a decrease in runoff may occur during both summer and winter months in the east and southeast. It is in these areas that current demand for water is greatest and where there is likely to be the most rapid increase in demand, mainly as a result of projected population growth. This is especially true for the Greater Dublin region, where the water supply infrastructure will come under growing pressure in the near future, especially during the summer months (Department of the Environment, 1996). A widespread reduction in runoff would also lead to a number of water quality problems. Although the estimates made here are for seasonal runoff, it is not unreasonable to assume that the frequency and duration of low flows might also increase. This, combined with the projected growth of urban areas, would increase the volume of sewage to be treated and the quantity of effluent discharged into rivers, many of which would not have sufficient capacity to dilute it.

The estimated reduction in runoff is coupled with a corresponding decrease in soil moisture and a significant soil moisture deficit that develops during the summer months over most of the east of the country. This would lead to a considerable increase in demand from agriculture for irrigation water. At present approximately $10 \%$ of total water consumption in the Republic of Ireland is accounted by this sector (Gleick, 1993); this is relatively low since irrigation is only required on a limited scale in the east of the country. Holden et al. (2003) suggest that under future climate scenarios there could be major changes in the crops grown, their performance, and the distribution of land use; these factors could further affect patterns of water use.

Even without the superimposed effects of climate change, the projected increase in urban demand necessitates the identification and development of new water supplies. Possible options currently under investigation for the greater Dublin region include enhancing the flow of the Liffey (which currently supplies most of Dublin's water) by pumping water from the headwaters of the Barrow, which rises in the Wicklow Mountains; or transferring water from the Shannon. The decrease in runoff indicated by this preliminary research could greatly reduce the yield and sustainability of both schemes, especially during the summer months where water demand will probably increase in response to dryer conditions. The conjunctive use of groundwater is another possibility for enhancing supply and significant groundwater resources are currently unused for water supply (Daly and Warren, 1998) could be exploited. In doing this it would be necessary to consider the climate change implications of reduced recharge to aquifers and the role of groundwater in 
maintaining low flows under the climate scenarios considered. The availability of groundwater in fissured and karstic aquifers, where there is a rapid throughput of water, could be significantly reduced during the drier months.

The implications of this study for increases in flood magnitude and frequency can only be discussed in very general terms because the coarse temporal resolution did not allow the estimation of changes in flood magnitude and frequency. It is possible that in much of the western half of the country there will be an increased incidence of flooding, with a greater area being at risk of flooding on a frequent basis in future. In management terms, the role of land use change in increasing the flood risk, and the encroachment of urban development onto floodplains should be considered in all aspects of planning, as this will exacerbate any climate-induced changes. This is particularly important where new areas are urbanised since impermeable surfaces, drains and sewers rapidly transfer water to river channels, resulting in a reduced response time and an increase in peak flow. Widespread flooding took place throughout the country in November 2000 and again in November 2001 and may, in some cases, have been exacerbated by floodplain development. Further research is required to allow the delimitation of risk areas, to define confidence limits and to quantify flood return periods and magnitudes to inform management decisions.

\section{Conclusions}

This is the first time that downscaled GCM predictions have been used to model effective runoff for the whole land area of Ireland under future climate scenarios. Since this was a first pass investigation it was necessary to make a number of simplifying assumptions and, in common with other studies of this type, several sources of uncertainty were introduced at different stages during the modeling process. Despite the assumptions made, the results of the model validation carried out were considered to be reasonable given the limitations of the study and generally fell within the range that might be expected. The results suggest a widespread reduction in annual runoff under both climate scenarios, which is most marked in the east and southeast of country. A slight increase in annual runoff may be observed for a limited part of the northwest. All areas were found to experience a decrease in summer runoff, with the greatest reductions in the east of the country. It is possible that the frequency and duration of low flows could increase in many areas and long term deficits in soil moisture, aquifers, lakes and reservoirs are also likely to develop. Winter runoff was found to increase in the west of the country, especially under the 2061-2090 scenario where an increase in winter runoff was simulated for over $60 \%$ of the land area. The greatest increases occurred in the northwest and the results suggest that the magnitude and frequency of individual flood events might increase in the western half of the country. In management terms the uncertainties, clearly go beyond those associated with the modeling process. 
Improvement in the hydrological estimation of climate change will better inform management decisions.

Given the findings presented here, future work will move away from the gridbased approach towards employing the catchment as the basic unit of investigation. In order to allow a more detailed analysis of the frequency and magnitude of extreme events under a changed climate, climate data of a monthly time step will be replaced with daily data. Given this evolution of the adopted methodology many of the limitations of the current study may be addressed in greater detail. More stringent validation requirements have been established with the model being tested both annually and seasonally and the transferability of parameter sets being examined over both wet and dry periods. Ongoing work is examining the sensitivity and stability of the HYSIM framework so that sources of uncertainty relating to model input, model structure and the parameterization and calibration processes can be highlighted and quantified, thus enabling confidence bounds to be attributed to simulated output.

\section{Acknowledgments}

This research forms part of the Environmental RTDI Programme 2000-2006, developed and managed by the Environmental Protection Agency (Ireland) and funded by the National Development Plan.

\section{References}

Arnell, N.: 1992, 'Impacts of climatic change on river flow regimes in the UK', J. Inst. Water Environ. Manag. 6, 432-442.

Arnell, N.: 1996, Global Warming, River Flows and Water Resources. Wiley, Chichester.

Arnell, N. and Reynard, N. S.: 1993, Impact of Climate Change on River Flow Regimes in the United Kingdom. Report to the Department of the Environment, Institute of Hydrology, Wallingford.

Arnell, N. and Reynard, N. S.: 1996, 'The effects of climate change due to global warming on river flows in Great Britain', J. Hydrol. 183, 397-424.

Boorman, D. B. and Sefton, C. E. M.: 1997, 'Recognising the uncertainty in the quantification of the effects of climate change on hydrological response', Clim. Change 35, 415-434.

Conway, D. 1998, 'Recent climate variability and future climate change scenarios for Great Britain', Prog. Phys. Geog. 22(3), 350-374.

Cunnane, C. and Regan, S.: 1994, 'Hydrology and Freshwater Resources', in McWilliams, B.E. (ed), Climate Change: Studies of the Implications for Ireland. Department of the Environment, Stationery Office, Dublin, pp. 89-108.

Daly, D. and Warren, W. P.: 1998, 'Mapping Groundwater Vulnerability: the Irish Perspective', in Robbins, N. S. (ed.) Groundwater Pollution, Aquifer Recharge and Vulnerability. Geol. Soc. (London) Special Publication, No. 30, pp. 179-190.

Department of the Environment: 1996, Greater Dublin Water Supply Strategic Study. Department of the Environment, Dublin.

Galvin, L. F.: 1976, 'Physical properties of Irish Peats', Irish J. Agric. Res. 15, 207-221.

Gardiner, M. J. and Radford, T.: 1980a, Ireland, General Soil Map. National Soil Survey, Dublin. 
Gardiner, M. J. and Radford, T.: 1980b, Soil Associations of Ireland and Their Land Use Potential. National Soil Survey, Dublin.

Gleick, P. H.: 1993, Water in Crisis. A Guide to the World's Fresh Water Resources. Oxford University Press, Oxford, p. 377.

Goodale, C., Aber, J., and Ollinger, S.: 1998, 'Mapping monthly precipitation, temperature and solar radiation for Ireland with polynomial regression and a digital elevation model', Clim. Res. 10, $35-48$.

Feehan, J. and O'Donovan, G.: 1996, The Bogs of Ireland: An Introduction to the Natural, Cultural and Industrial Heritage of Irish Peatlands. Environmental Institute, University College Dublin.

Holden, N. M., Brereton, A. J., Fealy, R., and Sweeney, J.: 2003, 'The predicted change in Irish climate and its impact on barley and potato yields.' Agricultural and Forest Meteorology 116(3/4), 181-196.

Houghton, J. and Cinneide, M. O.: 1976, 'Distribution and synoptic origin of selected heavy precipitation storms over Ireland', Irish Geog. 9, 1-8.

Hulme, M. and Barrow, E., (eds.): 1997, Climates of the British Isles: Present, Past and Future. Routledge, New York.

Kiely, G.: 1999, 'Climate change in Ireland from Precipitation and stream flow observations', $A d v$. Water Res. 23, 141-151.

Lovelace, N.: 2000, 'Ofwat Spending Limits Hamper Flood Control, Say Water Firms', NCE New Civil Engineer (Magazine of the Institution of Civil Engineers), 16 November 2000, EMAP Construct Publication.

Manley, R. E.: 1978, 'Simulation of flows in ungauged basins', Hydrol. Sci. Bull. 23, 85-101.

Manley, R. E.: 1993, HYSIM Reference Manual. R.E. Manley Consultancy, Cambridge.

O'Sullivan, G. (ed.): 1994, CORINE Land Cover Project (Ireland). Project Report, December 1994. Ordnance Survey of Ireland, Dublin and Ordnance Survey of Northern Ireland Belfast.

Palutikof, J. P., Winkler, J. A., Goodess, C. M., and Andresen, J. A.: 1997, 'The simulation of daily temperature time series from GCM output. Part 1: Comparison of model data with observations', J. Clim. 12, 1480-1489.

Pilling, C. and Jones, J. A. A.: 2002, 'The impact of future climate change on seasonal discharge, hydrological processes and extreme flows in the Upper Wye experimental catchment, Mid-Wales', Hydrol. Process. 16, 1201-1213.

Pilling, C. and Jones, J. A. A.: 1999, 'High resolution climate change scenarios: Implications for British runoff', Hydrol. Process. 13, 2877-2895.

Shorthouse, C. and Arnell, N.: 1999, 'The effects of climate variability on spatial characteristics of European river flows', Phys. Chem. Earth (B) 24(1-2), 7-13.

Sweeney, J. C.: 1985, 'The changing synoptic origins of Irish precipitation', Trans. Inst. Brit. Geog., N.S. 10, 467-480.

Sweeney, J. C. and O’Hare, G.: 1992, 'Geographical variations on precipitation yields and circulation types in Britain and Ireland', Trans. Inst. Brit. Geog., N.S. 17, 448-463.

Sweeney, J. C.: 2000, 'A three-century storm climatology for Dublin 1715-2000', Irish Geog. 33(1), $1-14$.

Sweeney, J. C.: 1997, 'Ireland', in Wheeler, D., and Mayes, J. (eds.), Regional Climates of the British Isles. Routledge, London, pp. 254-275.

Sweeney, J. C.: 1994, 'Climate scenarios for Ireland', in Feehan, J. (ed), Climate Variations and Climate Change in Ireland. Environmental Institute, University College, Dublin, pp. 110-127.

(Received 5 February 2003; in revised form 16 November 2004) 